\title{
Vegetable quality and safety supervision technology Integration solutions and evaluation
}

\author{
Ma Chen ${ }^{1,2, a}$, Li Jin ${ }^{1,2, b}$
}

${ }^{1}$ Beijing Academy of Agriculture and Forestry Sciences

${ }^{2}$ Beijing Research Center for Information Technology in Agriculture Beijing, P. R. China

Building A, Beijing Nongke Mansion, NO.11 ShuguangHuayuan Middle Road, Banjing, Haidian District, Beijing, 100097, P.R.China

aemail:mac@nercita.org.cn

b*email: lij@nercita.org.cn

Keywords: Quality safety; Supervision technology; Evaluation

Abstract. Based on carding the technology integration theory of vegetable quality and safety, this article proposed Vegetables quality and safety monitoring technology integration solutions, and selected the evaluation method to evaluate the vegetable quality and safety supervision information technology in Beijing six gold rings NongYeYuan.

\section{Introduction}

Meaning of technology integration."Integration" is essentially an idea and methodas the guidance of system science theory.Lansiti (1995) first proposed a "TechnologyIntegration"concept; he believes technology integration is a more effective innovation management methods and procedures,because it combines each tiny elements of new and old technology as an organic wholein reasonable structure. Technology integration is essentially a process of innovative and existing technologiescross-integration. In the integration process, a variety of optional technology need for evaluation, selection and matchingto achieve organic integration of multiple functions.

Theoretical overview of Vegetable quality and safety supervision integration ideas. The internal logic of the study can be summarized in four dimensions; The first dimension:Around the "value target", clearly the main demand, including the main choice needs, integration requirements and optimize demand for technology; The second dimension: Focus on "technical sources", clear technical classification, including key technologies and supporting technologies based on key and critical control points; The third dimension: Focus on "technical evaluation", deepening technology integration, including high-level integration, intermediate-levelintegration and low-level integration; The fourth dimension: Focus on "technology systematic", conduct equipment (facilities) configuration, including high-level configuration, intermediate-level configuration and low-level configuration.

\section{Integrated solutions of Vegetable quality and safety supervision technology}

Integrated solutions of Vegetable quality and safety supervision technology is shown in Table 1.

Table 1.Integrated solutions of Vegetable quality and safety supervision technology

\begin{tabular}{|c|l|l|l|l|}
\hline Name & \multicolumn{1}{|c|}{ Content } & \multicolumn{1}{|c|}{ Conditions } & $\begin{array}{l}\text { Applicable } \\
\text { area }\end{array}$ & $\begin{array}{l}\text { Function and } \\
\text { effect }\end{array}$ \\
\hline & $\begin{array}{l}\text { 1.The highly integrated } \\
\text { and joint monitoring of }\end{array}$ & $\begin{array}{l}\text { Suitable the group } \\
\text { company Applicable to }\end{array}$ & $\begin{array}{l}\text { High } \\
\text { and } \\
\text { the technical } \\
\text { technology } \\
\text { 1.High-end } \\
\text { integration }\end{array}$ \\
$\begin{array}{l}\text { information technology } \\
\text { equipment and key } \\
\text { technologies; } \\
\text { 2. The application of } \\
\text { very high demand for } \\
\text { quality and safety of } \\
\text { agricultural products, }\end{array}$ & $\begin{array}{l}\text { Vegetable } \\
\text { quality and } \\
\text { safety }\end{array}$ & $\begin{array}{l}\text { equipment } \\
\text { costs, } \\
\text { accuracy and }\end{array}$ \\
\hline
\end{tabular}




\begin{tabular}{|c|c|c|c|c|}
\hline & $\begin{array}{l}\text { information technology } \\
\text { equipment runs through } \\
\text { all aspects of the whole } \\
\text { industry chain. }\end{array}$ & $\begin{array}{l}\text { with strong economic } \\
\text { strength and large, } \\
\text { business coverage from } \\
\text { agricultural production } \\
\text { to sales of the whole } \\
\text { industry chain } \\
\text { enterprises and } \\
\text { organizations Group }\end{array}$ & $\begin{array}{l}\text { supervision } \\
\text { in the mature } \\
\text { stage of } \\
\text { farmers and } \\
\text { regions. }\end{array}$ & $\begin{array}{l}\text { good } \\
\text { controllability. }\end{array}$ \\
\hline $\begin{array}{l}2 . \\
\text { Mid } \\
\text { Integration }\end{array}$ & $\begin{array}{l}\text { 1.Senior integrated and } \\
\text { joint monitoring of } \\
\text { information technology } \\
\text { equipment and key } \\
\text { technologies; } \\
\text { 2.In industry chain, } \\
\text { choose the impact on } \\
\text { some of the larger quality } \\
\text { and safety of agricultural } \\
\text { products link for } \\
\text { application of information } \\
\text { technology equipment. }\end{array}$ & $\begin{array}{l}\text { It is suitable for larger } \\
\text { enterprises } \\
\text { organizations which } \\
\text { require a higher quality } \\
\text { and safety of } \\
\text { agricultural products, } \\
\text { and involve only a few } \\
\text { aspects of agricultural } \\
\text { production, processing, } \\
\text { distribution or sale of } \\
\text { enterprises and } \\
\text { organizations. }\end{array}$ & $\begin{array}{l}\text { Applicable to } \\
\text { the technical } \\
\text { level of } \\
\text { Vegetable } \\
\text { quality and } \\
\text { safety } \\
\text { supervision } \\
\text { in the mature } \\
\text { stage of } \\
\text { farmers and } \\
\text { regions. }\end{array}$ & $\begin{array}{l}\text { Technology } \\
\text { costs and } \\
\text { equipment } \\
\text { costs are } \\
\text { high-end, } \\
\text { better } \\
\text { accuracy and } \\
\text { controllability }\end{array}$ \\
\hline $\begin{array}{l}\text { 3.Mid-low } \\
\text { integration }\end{array}$ & $\begin{array}{l}\text { 1. Middle integrated and } \\
\text { joint monitoring of } \\
\text { information technology } \\
\text { equipment and key } \\
\text { technologies; } \\
2 . \text { In industry chain, } \\
\text { choose the impact on } \\
\text { some of the larger quality } \\
\text { and safety of agricultural } \\
\text { products link for } \\
\text { application of information } \\
\text { technology equipment. }\end{array}$ & $\begin{array}{l}\text { Suitable for small and } \\
\text { medium-sized } \\
\text { enterprises and } \\
\text { organizations which } \\
\text { require the general } \\
\text { quality and safety of } \\
\text { agricultural products. } \\
\text { And their business only } \\
\text { involves in one or a few } \\
\text { aspects of agricultural } \\
\text { production, processing, } \\
\text { distribution or sale. }\end{array}$ & $\begin{array}{l}\text { Applicable to } \\
\text { the technical } \\
\text { level of } \\
\text { Vegetable } \\
\text { quality and } \\
\text { safety } \\
\text { supervision } \\
\text { in the } \\
\text { development } \\
\text { stage of } \\
\text { farmers and } \\
\text { regions }\end{array}$ & $\begin{array}{l}\text { Technology } \\
\text { costs and } \\
\text { equipment } \\
\text { costs are } \\
\text { low-end, } \\
\text { accuracy and } \\
\text { controllability } \\
\text { in general. }\end{array}$ \\
\hline $\begin{array}{l}\text { 4.Low-end } \\
\text { integration }\end{array}$ & $\begin{array}{l}\text { 1.Low integrated and } \\
\text { joint monitoring of } \\
\text { information technology } \\
\text { equipment and key } \\
\text { technologies; } \\
\text { 2.In the industry chain, } \\
\text { there is no application of } \\
\text { information technology } \\
\text { equipment. }\end{array}$ & $\begin{array}{l}\text { Suitable for poor } \\
\text { Economic strength } \\
\text { enterprises and } \\
\text { organizations which } \\
\text { require the lower quality } \\
\text { and safety of } \\
\text { agricultural products. } \\
\text { And their business only } \\
\text { involves in one aspects } \\
\text { of agricultural } \\
\text { production, processing, } \\
\text { distribution or sale. }\end{array}$ & $\begin{array}{l}\text { Applicable to } \\
\text { the technical } \\
\text { level of } \\
\text { Vegetable } \\
\text { quality and } \\
\text { safety } \\
\text { supervision } \\
\text { in the early } \\
\text { stage of } \\
\text { farmers and } \\
\text { regions }\end{array}$ & $\begin{array}{l}\text { Technology } \\
\text { costs and } \\
\text { equipment } \\
\text { costs are } \\
\text { low-end, poor } \\
\text { accuracy and } \\
\text { controllability. }\end{array}$ \\
\hline
\end{tabular}


Integration solutions evaluation of Vegetable quality and safety supervision technology

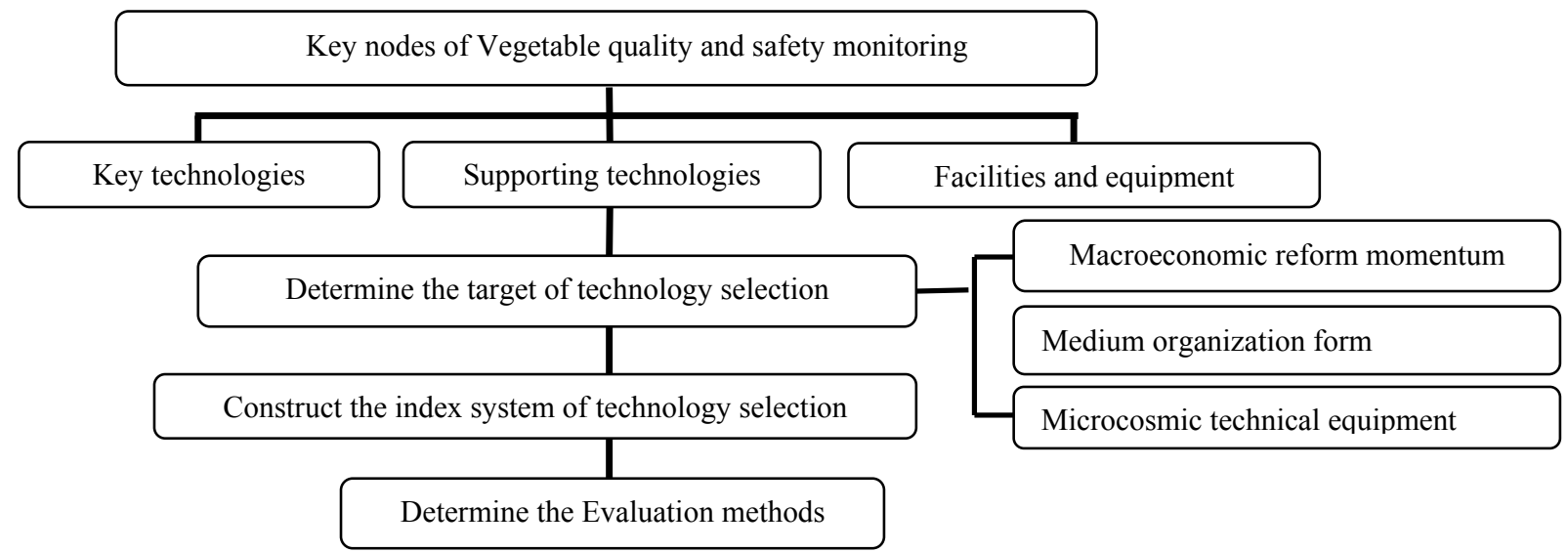

Fig. 1. Research Framework

Overview of evaluation methods. Vegetable product quality and safety supervision technology integration involves different aspects and control points,and every link and control points are composed of different technologies, which exist between crisscross complex interactions. Therefore, in this study, The idea of technical evaluation is to in-depth the technical system itself,to start from thekey link and key control points in the system, through combing the relevant technologyand equipment,to determine the technical optionsgoal, and according to the key to determine the corresponding index system of technology selection (It is shown in Fig.1). This study mainly uses the scoring method.

Construction of Evaluation Index System. Technology selection index system through the quantitative evaluation of each critical control point, adopt the method of grade analysis to analyzefeatures and flexibility of each level. We have got the preliminary technology selection index system.

The index system includes 5 level indicators and 17 level two indexes. Level indicators include environmental and investment monitoring, production process control, storage management, distribution management and technical equipment adaptability, and each first level index are divided into a plurality of secondary indicators.

Table 2.Technology selection index system of Vegetable quality and safety supervision information

\begin{tabular}{|c|c|c|c|}
\hline $\begin{array}{c}\text { Level } \\
\text { indicators }\end{array}$ & $\begin{array}{l}\text { Secondary } \\
\text { indicators }\end{array}$ & Interpretation & Scoring criteria \\
\hline \multirow{4}{*}{$\begin{array}{l}\text { Monitoring of } \\
\text { the } \\
\text { environment } \\
\text { and the } \\
\text { inputs }\end{array}$} & Air & $\begin{array}{l}\text { Monitoring of major air } \\
\text { pollutant }\end{array}$ & $\begin{array}{l}\text { The monitoring level and } \\
\text { ability for air pollutants } \\
\text { indicator : High-level : } 5 \text {; } \\
\text { General level : } 3 \text {; Can't } \\
\text { monitor : } 1\end{array}$ \\
\hline & Soil & $\begin{array}{l}\text { Monitoring of heavy } \\
\text { metals in soil }\end{array}$ & $\begin{array}{l}\text { The monitoring level and } \\
\text { ability for indicators of heavy } \\
\text { metals in soil : High-level : } 5 \text {; } \\
\text { General level : } 3 \text {; Can't } \\
\text { monitor : } 1\end{array}$ \\
\hline & Surface water & $\begin{array}{l}\text { Monitoring of surface } \\
\text { water quality }\end{array}$ & $\begin{array}{l}\text { The monitoring level and } \\
\text { ability for surface water } \\
\text { quality :High-level :5;General } \\
\text { level : } 3 \text {; Can't monitor : } 1\end{array}$ \\
\hline & Inputs & Quality monitoring of & The monitoring level and \\
\hline
\end{tabular}




\begin{tabular}{|c|c|c|c|}
\hline & & $\begin{array}{lr}\text { seeds, } & \text { pesticides, } \\
\text { fertilizers, } & \text { agricultural } \\
\text { film } & \end{array}$ & $\begin{array}{l}\text { ability for Inputs: High-level : } \\
5 \text {; General level : } 3 \text {; Can't } \\
\text { monitor : } 1\end{array}$ \\
\hline \multirow{4}{*}{$\begin{array}{l}\text { Manufacturing } \\
\text { process } \\
\text { control }\end{array}$} & $\begin{array}{l}\text { Environmental } \\
\text { Control }\end{array}$ & $\begin{array}{l}\text { Control of temperature } \\
\text { and humidity, } \mathrm{CO}_{2} \text {, etc. } \\
\text { in the process of } \\
\text { production }\end{array}$ & $\begin{array}{l}\text { The control ability and level for } \\
\text { environmental: High-level : } 5 \text {; } \\
\text { General level : } 3 \text {; Can't } \\
\text { monitor : } 1\end{array}$ \\
\hline & Fertilizer & $\begin{array}{l}\text { Control of chemical } \\
\text { fertilizer and application } \\
\text { time in the process of } \\
\text { production }\end{array}$ & $\begin{array}{l}\text { The control ability and level for } \\
\text { fertilizer: High-level : } 5 \text {; } \\
\text { General level : } 3 \text {; Can't } \\
\text { monitor : } 1\end{array}$ \\
\hline & Pesticide & $\begin{array}{l}\text { Control of the amount of } \\
\text { pesticide spraying and } \\
\text { spraying time in the } \\
\text { process of production }\end{array}$ & $\begin{array}{l}\text { The control ability and level for } \\
\text { application of pesticides: } \\
\text { High-level : } 5 \text {; General level : } \\
3 \text {; Can't monitor : } 1\end{array}$ \\
\hline & Irrigation water & $\begin{array}{l}\text { Control of irrigation } \\
\text { water usage and } \\
\text { application time in the } \\
\text { process of production }\end{array}$ & $\begin{array}{l}\text { The control ability and level for } \\
\text { irrigation water use: } \\
\text { High-level : } 5 \text {; General level : } \\
3 \text {; Can't monitor : } 1\end{array}$ \\
\hline \multirow{2}{*}{$\begin{array}{l}\text { Storage and } \\
\text { Processing } \\
\text { Management }\end{array}$} & Fresh control & $\begin{array}{l}\text { Control of agricultural } \\
\text { storage temperature, } \\
\text { humidity and time }\end{array}$ & $\begin{array}{l}\text { The control ability and level for } \\
\text { storage and preservation of } \\
\text { agricultural products: } \\
\text { High-level : } 5 \text {; General level : } \\
3 \text {; Can't monitor : } 1\end{array}$ \\
\hline & Inspection & $\begin{array}{l}\text { Test of pesticide } \\
\text { residues and microbial } \\
\text { after agricultural } \\
\text { products harvest }\end{array}$ & $\begin{array}{l}\text { Detection of information } \\
\text { openness and transparency: } \\
\text { High-level : } 5 \text {; General level : } \\
3 \text {; Can't monitor : } 1\end{array}$ \\
\hline \multirow{4}{*}{$\begin{array}{l}\text { Circulation } \\
\text { Distribution } \\
\text { Management }\end{array}$} & $\begin{array}{l}\text { Identification } \\
\text { traceability }\end{array}$ & $\begin{array}{l}\text { Information } \\
\text { identification device } \\
\text { such as RFID, the } \\
\text { two-dimensional code, } \\
\text { etc. }\end{array}$ & $\begin{array}{l}\text { Identification } \\
\text { traceability: } 1 ; \text { No logo or can't } \\
\text { be retroactive : } 0\end{array}$ \\
\hline & $\begin{array}{l}\text { Environmental } \\
\text { control in the } \\
\text { circulation } \\
\text { distribution vehicle }\end{array}$ & $\begin{array}{lr}\text { To control the } \\
\text { temperature } & \text { and } \\
\text { humidity inside the } \\
\text { vehicle }\end{array}$ & $\begin{array}{l}\text { The ability to control } \\
\text { temperature and humidity } \\
\text { inside the vehicle: Very strong: } \\
\text { 5; General: } 3 \text {; does not control: } \\
1\end{array}$ \\
\hline & Vehicle Location & $\begin{array}{l}\text { GPRS positioning } \\
\text { system in the vehicle }\end{array}$ & $\begin{array}{l}\text { Positioning } \\
\text { system: } 1 \text {; No positioning } \\
\text { system: } 0\end{array}$ \\
\hline & Electronic Trading & $\begin{array}{l}\text { Order online, electronic } \\
\text { trading }\end{array}$ & $\begin{array}{l}\text { Electronic trading system }: 1 ; \\
\text { No electronic trading system }: 0\end{array}$ \\
\hline
\end{tabular}




\begin{tabular}{|l|l|l|l|}
\hline \multirow{3}{*}{$\begin{array}{l}\text { Technical } \\
\text { equipment } \\
\text { adaptability }\end{array}$} & $\begin{array}{l}\text { Maturity of the } \\
\text { technology } \\
\text { equipment }\end{array}$ & $\begin{array}{l}\text { and } \\
\text { stages of technical } \\
\text { equipment from } \\
\text { research to industrial } \\
\text { process }\end{array}$ & Industry: 5; Pilot: 3; R \& D: 1 \\
\cline { 2 - 5 } & $\begin{array}{l}\text { Degree of quality and } \\
\text { safety protection } \\
\text { acceptance }\end{array}$ & $\begin{array}{l}\text { The ability to protect the } \\
\text { safety of the quality } \\
\text { with this set of technical } \\
\text { equipment }\end{array}$ & $\begin{array}{l}\text { Very recognized: 5; Average: 3; } \\
\text { Not recognized: 1 }\end{array}$ \\
$\begin{array}{l}\text { Quality safety guarantees } \\
\text { 3; can't guarantee: 1 }\end{array}$ \\
\hline
\end{tabular}

Evaluation method. Vegetable quality and safety regulatory mode evaluation index system is established. In order to accurately measure the pros and cons of the vegetable quality and safety regulatory model, the index weight and integrated measurement is also needed to determine. Determination of the Indicators weights: the scoring method.

Comprehensive index score is calculated as:

$$
\Pi=\sum_{i=1}^{n} W_{i} \quad\left(\sum_{j=1}^{m} W_{i j} \quad P i j \quad\right)
$$

The II represents information technology index composite scores, $\mathrm{n}$ is composed various index element number, $M$ means the index number of the I element, Pij $I$ is the elements of the $\mathrm{j}$ standards value, Wij is the elements of $\mathrm{j}$ index weight.

Determining the weights of the index system. Weights of the index system of vegetable quality and safety supervision information technology are shown in Table 3.

Table 3. Weights of the index system of vegetable quality and safety supervision information

\begin{tabular}{|c|c|c|c|c|}
\hline \multicolumn{5}{|c|}{ technology } \\
\hline $\begin{array}{c}\text { Level } \\
\text { indicators }\end{array}$ & Weights & $\begin{array}{l}\text { Secondary } \\
\text { indicators }\end{array}$ & Weights & Interpretation \\
\hline \multirow{4}{*}{$\begin{array}{l}\text { Monitoring of } \\
\text { the } \\
\text { environment } \\
\text { and the } \\
\text { inputs }\end{array}$} & \multirow{4}{*}{0.2353} & Air & 0.0235 & Monitoring of major air pollutant \\
\hline & & Soil & 0.0471 & Monitoring of heavy metals in soil \\
\hline & & Surface water & 0.0706 & Monitoring of surface water quality \\
\hline & & Inputs & 0.0941 & $\begin{array}{l}\text { Quality monitoring of seeds, pesticides, } \\
\text { fertilizers, agricultural film }\end{array}$ \\
\hline \multirow{4}{*}{$\begin{array}{l}\text { Manufacturing } \\
\text { process } \\
\text { control }\end{array}$} & \multirow{4}{*}{0.2353} & $\begin{array}{l}\text { Environmental } \\
\text { Control }\end{array}$ & 0.0941 & $\begin{array}{l}\text { Control of temperature and humidity, } \mathrm{CO}_{2} \text {, } \\
\text { etc. in the process of production }\end{array}$ \\
\hline & & Fertilizer & 0.0471 & $\begin{array}{l}\text { Control of chemical fertilizer and } \\
\text { application time in the process of } \\
\text { production }\end{array}$ \\
\hline & & Pesticide & 0.0471 & $\begin{array}{l}\text { Control of the amount of pesticide spraying } \\
\text { and spraying time in the process of } \\
\text { production }\end{array}$ \\
\hline & & $\begin{array}{l}\text { Irrigation } \\
\text { water }\end{array}$ & 0.0471 & $\begin{array}{l}\text { Control of irrigation water usage and } \\
\text { application time in the process of } \\
\text { production }\end{array}$ \\
\hline \multirow{2}{*}{$\begin{array}{l}\text { Storage and } \\
\text { Processing } \\
\text { Management }\end{array}$} & \multirow{2}{*}{0.1765} & Fresh control & 0.0588 & $\begin{array}{l}\text { Control of agricultural storage temperature, } \\
\text { humidity and time }\end{array}$ \\
\hline & & Inspection & 0.1175 & $\begin{array}{l}\text { Test of pesticide residues and microbial } \\
\text { after agricultural products harvest }\end{array}$ \\
\hline $\begin{array}{l}\text { Circulation } \\
\text { Distribution } \\
\text { Management }\end{array}$ & 0.2059 & $\begin{array}{l}\text { Identification } \\
\text { and } \\
\text { traceability }\end{array}$ & 0.0824 & $\begin{array}{l}\text { Information identification device such as } \\
\text { RFID, the two-dimensional code, etc. }\end{array}$ \\
\hline
\end{tabular}




\begin{tabular}{|l|l|l|l|l|}
\hline & & $\begin{array}{l}\text { Environmental } \\
\text { control in the } \\
\text { circulation } \\
\text { distribution } \\
\text { vehicle }\end{array}$ & 0.0618 & $\begin{array}{l}\text { To control the temperature and humidity } \\
\text { inside the vehicle }\end{array}$ \\
\cline { 3 - 4 } & $\begin{array}{l}\text { Vehicle } \\
\text { Location }\end{array}$ & 0.0206 & GPRS positioning system in the vehicle \\
\hline & $\begin{array}{l}\text { Electronic } \\
\text { Trading }\end{array}$ & 0.0412 & Order online, electronic trading \\
\hline \multirow{2}{*}{$\begin{array}{l}\text { Technical } \\
\text { equipment } \\
\text { adaptability }\end{array}$} & $\begin{array}{l}\text { Maturity of } \\
\text { the technology } \\
\text { and equipment }\end{array}$ & 0.0490 & $\begin{array}{l}\text { Different successional stages of technical } \\
\text { equipment from research to industrial } \\
\text { process }\end{array}$ \\
\cline { 2 - 5 } & $\begin{array}{l}\text { User } \\
\text { acceptance }\end{array}$ & 0.0245 & Degree of user acceptance \\
\hline & $\begin{array}{l}\text { Degree of } \\
\text { quality } \\
\text { andsafety } \\
\text { protection }\end{array}$ & 0.0735 & $\begin{array}{l}\text { The ability to protect the safety of the } \\
\text { quality with this set of technical equipment }\end{array}$ \\
\hline
\end{tabular}

\section{Scoring criteria and classification.}

(1)High-end integration (Scoring criteria: 5)

Appropriate objects: It is suitable for group businesses and organizations which has the high requirements for agricultural products quality and safety, and cover the whole industry chain from agricultural production to the sales.

(2)Mid Integration (Scoring criteria: 3-5)

Appropriate objects: It is suitable for larger enterprises and organizations which require a higher quality and safety of agricultural products, and involve only a few aspects of agricultural production, processing, distribution or sale of enterprises and organizations.

(3)Mid-low integration (Scoring criteria: 0.8558-3)

Appropriate objects: Suitable for small and medium-sized enterprises and organizations which require the general quality and safety of agricultural products. And their business only involves in one or a few aspects of agricultural production, processing, distribution or sale.

(4)Low-end integration (Scoring criteria: 0.8558)

Appropriate objects: Suitable for poor Economic strength enterprises and organizations which require the lower quality and safety of agricultural products. And their business only involves in one aspects of agricultural production, processing, distribution or sale.

\section{Conclusion}

We choose Beijing six gold rings NongYeYuan as a base for the application.After the weighted calculation, the vegetable quality and safety supervision informationization level value is 3.5 points, in the high-end level.The conclusion shows that the rapid development and vigorous application of wireless sensor network, 3G,mobile Internet and other information technologies, promote the leap forward development of the agriculturepark. The information equipment, such as mobile wireless sensor network system etc., makes the Beijing six gold rings NongYeYuan be in the leading position in the application of agricultural information technology, and have distinctive exemplary role.

\section{Acknowledgments}

This work was supported in Beijing Academy of Agriculture and Forestry Sciences Special fund for science and technology innovation capability construction (KJCX20140501). 


\section{References}

[1]Higgins V, Dibden J and Cocklin C, J. Rural Studies, 1(2008)

[2]WangKaiyi, Zhao Chunjiang and Zhang Fangtian, J. Transactions of the Chinese Society of Agricultural Engineering, 23, 5(2007)

[3]Bowles J B and Pela`ez C E, J. Reliability Engineering and System Safety, 50(1995)

[4]Train.K.Optimal Regulation, Editor, The EeonomicThenry of Natural Monopoly, MIT Press, Cambridge, MA (1991)

[5]WangJihua, J. ActaAgriculturae Shanghai, 26, 1(2010) 